\title{
Variations
}

Variations Revue internationale de théorie critique

$16 \mid 2012$

Tahrir is here !

\section{Chat noir chat blanc}

\section{David Querien}

\section{(2) OpenEdition \\ Journals}

Édition électronique

URL : http://journals.openedition.org/variations/198

DOI : 10.4000/variations. 198

ISSN : 1968-3960

\section{Éditeur}

Les amis de Variations

\section{Édition imprimée}

Date de publication : 16 janvier 2012

\section{Référence électronique}

David Querien, « Chat noir chat blanc », Variations [En ligne], 16 | 2012, mis en ligne le 20 février 2012, consulté le 19 avril 2019. URL : http://journals.openedition.org/variations/198 ; DOI : 10.4000/ variations. 198

Ce document a été généré automatiquement le 19 avril 2019.

Les ami•e•s de Variations 


\title{
Chat noir chat blanc
}

\author{
David Querien
}

\section{NOTE DE L'ÉDITEUR}

Première publication sur www.theoriecritique.com, « Tahrir is here ! », 16 janvier 2012, p.

139

1 Je suis chat noir, chat blanc,

Choix gris.

Toujours à cran, toujours épris,

Jamais aigri, même amaigri mon âme écrit,

Décrit mon temps.

Je suis chat noir, chat blanc,

Un chat sans thune, mais mis à prix.

J'apprécie l'eau-de-vie,

Hasta la victoria,

J'ai combattu de Varsovie à Pretoria.

J'ai fait des portées de chats partout dans le globe,

Des chats de gouttières et des panthères aux belles robes.

Je dérobe les valeurs de ceux qui veulent savoir l'avenir,

T'as cru que j'étais qui pour t'en avertir?

Je danse sur les routes,

Rêve dans les caravanes,

Crache de l'essence et parfume ma gorge aux gitanes.

Je mange des Whiskas au caviar,

Chicos en or,

Pleure sur ma guitare le dernier souffle d'un matador.

Je suis chat noir, chat blanc donc de toutes les couleurs,

Parcours le monde pour ses bruits et ses odeurs. 


\section{AUTEUR}

DAVID QUERIEN

Slameur et poête. 